\title{
Hypoxia reduces endothelin production by rat alveolar type II cells in primary culture
}

\author{
B. Crestani*, C. Odoux*, C. Rolland*, F. Moldovan $*$ P. Cornillet ${ }^{+}$, J. Fiet ${ }^{\ddagger}$, M. Aubier*
}

Hypoxia reduces endothelin production by rat alveolar type II cells in primary culture. B. Crestani, C. Odoux, C. Rolland, F. Moldovan, P. Cornillet, J. Fiet, M. Aubier. @ERS Journals Ltd 1998.

ABSTRACT: The purpose of the study was to describe endothelin (ET) production and to characterize the effect of hypoxia on preproendothelin-1 (preproET-1) messenger ribonucleic acid (mRNA) expression and ET secretion by rat type II pneumocytes in vitro.

Rat type II pneumocytes were incubated in a sealed chamber containing a normoxic $\left(21 \% \mathrm{O}_{2}\right)$ or hypoxic $\left(1 \% \mathrm{O}_{2}\right)$ atmosphere for increasing durations. Immunoreactive ET (irET) was measured in cell supernatants using a radioimmunoassay. Rat preproET-1 mRNA was detected by Northern blot.

Rat type II pneumocytes expressed preproET-1 mRNA, contained irET and secreted irET in a time-dependent manner. ET secretion was dependent on de novo ribonucleic acid (RNA) and protein synthesis. Hypoxia decreased irET secretion by $27 \%$ and reduced the steady-state level of preproET-1 mRNA by $60 \%$ whereas intracellular irET concentration was unchanged. Inhibition was partially reversible with the return to a normoxic atmosphere. Inhibition of nitric oxide synthesis did not prevent the inhibitory effect of hypoxia.

In conclusion, rat type II pneumocytes in primary culture secreted immunoreactive endothelin and expressed preproendothelin-1 messenger ribonucleic acid. Hypoxia reversibly reduced endothelin-1 production through a reduction of the steady-state preproendothelin-1 messenger ribonucleic acid level. Nitric oxide synthesis did not mediate the inhibitory effect of hypoxia.

Eur Respir J 1998; 11: 392-399.
*Institut National de la Santé et de la Recherche Médicale INSERM U 408, Faculté Xavier Bichat, Paris, France. ${ }^{\star}$ Laboratoire de Biologie Hormonale, Hôpital Saint Louis, Assistance Publique-Hôpitaux de Paris, France. ${ }^{+}$Laboratoire d'Hématologie, Hôpital Robert Debré, Reims, France

Correspondence: B. Crestani

Unité de Pneumologie

Hôpital Bichat

46 rue Henri Huchard

75877 Paris Cedex 18

France

Fax: 33140258818

Keywords: Alveolar epithelium

hypoxia

nitric oxide

pneumocytes

preproendothelin-1

Received: September 231996

Accepted after revision November 171997
Type II alveolar epithelial cells (ATII cells) have been shown to play a key role in the regulation of the alveolar space. ATII cells synthesize and secrete surfactant, control the volume and composition of the epithelial lining fluid and proliferate and differentiate into type I alveolar epithelial cells after injury in order to maintain the integrity of the alveolar wall. Moreover, ATII cells are ideally located to have a role in modulating the activation or proliferation state of macrophages, fibroblasts or endothelial cells, because of the close proximity of the cell types in the alveolar space.

The interactions between the alveolar epithelial cells and the other cells located in the alveoli are brought about by the secretion of mediators such as cytokines [1], but other mediators are probably involved in this phenomenon. Among these mediators, endothelin (ET)-1 a 21 amino acid peptide may play an important role. Indeed, beside its potent effect on the constriction of vascular and bronchial smooth muscle cells, ET-1 acts as a mitogen for different cell types, such as fibroblasts or smooth muscle cells [2]. ET-1 is also involved in the modulation of the inflammatory response through a direct effect on alveolar macrophages [3] or mastocytes [4].

It has been shown that hyperplastic alveolar epithelial cells express preproendothelin-1 (preproET-1) messenger ribonucleic acid (mRNA) and immunoreactive ET (irET)-
1 in the human fibrotic lung [5], although conflicting data exist [6]. Rat ATII cells in primary culture [7], and a cell line derived from rat ATII cells, have been shown to secrete ET-1 in vitro [8].

Hypoxia has been identified as an important modulator of ET-1 production by endothelial cells. Hypoxia increases ET-1 production by human umbilical vein endothelial cells [9], but decreases ET-1 production by rat lung endothelial cells [10]. The effect of hypoxia on ET-1 production by rat ATII cells has never been evaluated, despite the fact that ATII cells are potential targets for hypoxia in the alveolar space both in physiological (high altitude) and pathological (e.g. lung parenchyma consolidation) conditions.

Therefore, the aims of this study were: 1 ) to characterize the regulation of ET-1 production by rat ATII cells in primary culture under low oxygen tension; and 2) to evaluate the influence of nitric oxide on ET-1 production by rat ATII cells.

\section{Materials and methods}

\section{Reagents}

Tissue culture media and foetal bovine serum were obtained from Gibco BRL Life Technologies (Cergy Pontoise, 
France). Tissue culture plastic ware was from Costar (Cambridge, MA, USA). Chemicals were from Sigma (La Verpilliere, France).

\section{Rat alveolar type II cells isolation and culture}

ATII cells were isolated from adult pathogen-free male Sprague-Dawley rats (Charles River Breeders, St Aubin les Elbeuf, France) by enzymatic dissociation and purified by differential adherence to plastic as described previously [11]. One million cells were plated in each well of a 24 well cell-culture plate with $1 \mathrm{~mL}$ of Dulbecco's modified Eagle's medium (DMEM) containing 10\% foetal bovine serum, $10^{5} \mathrm{U} \cdot \mathrm{mL}^{-1}$ penicillin, $100 \mathrm{mg} \cdot \mathrm{L}^{-1}$ streptomycin and $0.25 \mathrm{mg} \cdot \mathrm{L}^{-1}$ amphotericin B (complete DMEM). After a $24 \mathrm{~h}$ period, nonadherent cells were removed by gently washing twice with phosphate buffered saline (PBS), fresh complete medium was replaced and the cells were used for the experiments.

In some experiments, ATII cells $\left(5 \times 10^{6}\right)$ were cultured in $10 \mathrm{~cm}$ cell culture dishes. At the end of the incubation time, the supernatants were recovered and the cell monolayers were immediately frozen by dipping in liquid nitrogen, and stored at $-80^{\circ} \mathrm{C}$ until ribonucleic acid (RNA) extraction. In some experiments, we measured irET secretion by the A549 cell line, a pulmonary epithelial cell line which has been used as a model of human ATII cells [1]. A549 cells were grown in complete DMEM in 24 well cell-culture plates.

\section{Conditions for achieving hypoxia}

ATII cells were exposed for different periods either to normal or low oxygen tensions in humidified air-tight $12 \mathrm{~L}$ Lwolff chambers with inflow and outflow valves (Lequeux, Paris, France). The chambers were flushed with preanalyzed gas mixtures. The chambers were continuously maintained at $37^{\circ} \mathrm{C}$. The desired oxygen mixtures (either normoxic: $5 \% \mathrm{CO}_{2} 95 \%$ air; or hypoxic: $1 \% \mathrm{O}_{2}, 5 \% \mathrm{CO}_{2}$, balance $\mathrm{N}_{2}$ ) were preanalysed (Compagnie Française des Produits de l'Oxygène, Paris, France) and infused into the incubators at a flow rate of $12 \mathrm{~L} \cdot \mathrm{min}^{-1}$, initially and at the end of the first $24 \mathrm{~h}$ culture period when the cells had to be cultured for more than $24 \mathrm{~h}$. The oxygen fraction was monitored in the gas outflow using an oximeter (Datex OT-101; Datex Instrumentarium Corp., Helsinki, Finland) in order to ascertain that the expected oxygen fraction was achieved in the incubator. Media gas determinations were made at the end of the exposure (ABL 512; Radiometer, Copenhagen, Denmark). The partial pressure of oxygen $\left(\mathrm{PO}_{2}\right)$ measured in the cell culture supernatants after $24 \mathrm{~h}$ and $48 \mathrm{~h}$ incubation was $5.7 \pm 0.1$ and $5.1 \pm 4.0 \mathrm{kPa}(43 \pm 1$ and $38 \pm 3 \mathrm{mmHg}$ ) with $1 \% \mathrm{O}_{2}$ and $13.8 \pm 0.4$ and $13.7 \pm 0.4$ $\mathrm{kPa}(104 \pm 3$ and $103 \pm 3 \mathrm{mmHg})$ with $21 \% \mathrm{O}_{2}(\mathrm{n}=3)$, respectively. These $\mathrm{PO}_{2}$ values are in the same range as those measured by other investigators with similar exposure systems [10]. Media pH values were 7.51 and 7.43 with $21 \% \mathrm{O}_{2}$ after 24 and $48 \mathrm{~h}$, respectively, and 7.49 and 7.47 with $1 \% \mathrm{O}_{2}$ after 24 and $48 \mathrm{~h}$, respectively. Cellular viability was assessed after 24 and $48 \mathrm{~h}$ of culture using the methyl-thiazol-tetrazolium (MTT) colorimetric assay [12]. At the end of the incubation period, the cell culture super- natants were recovered, immediately frozen and stored at $-80^{\circ} \mathrm{C}$ until ET assay. Cell monolayers were washed twice with PBS, then sonicated in $500 \mu \mathrm{L}$ PBS and the cellular protein concentration was measured using the Bradford protein assay [13].

\section{Pharmacological interventions}

In some experiments, ATII cells exposed for $24 \mathrm{~h}$ in a $1 \% \mathrm{O}_{2}$ atmosphere were transferred to a normoxic atmosphere for a $24 \mathrm{~h}$ incubation period in order to assess the reversibility of the action of hypoxia. In other experiments, the cells were cultured with cycloheximide (20 $\left.\mu \mathrm{g} \cdot \mathrm{mL}^{-1}\right)$ in order to inhibit protein synthesis, or with actinomycin $\mathrm{D}\left(5 \mu \mathrm{g} \cdot \mathrm{mL}^{-1}\right)$ in order to inhibit mRNA synthesis.

The effect of NO synthesis inhibition was assessed by culturing the cells in control conditions or supplemented with $0.5 \mathrm{mM}$ N-monomethyl-L-arginine (L-NMMA), (a stereospecific NO synthase inhibitor) or with $5 \mathrm{mM} \quad \mathrm{L}-$ arginine (L-Arg) or the combination of L-NMMA and L-Arg. In addition, we evaluated the effect of a nonarginine-based NO synthase inhibitor (S-methyl-isothiourea sulphate (thiourea), $1 \mathrm{mM}$ ) [14] and an NO donor (SIN-1, $0.1 \mathrm{mM}$ ) [15] on preproET-1 mRNA content in ATII cells.

\section{Northern blot analysis}

Rat preproET-1 mRNA and glyceraldehyde-phosphate dehydrogenase (GAPDH) mRNA were detected by a Northern blot analysis and quantified through an electronic autoradiography device (Instant Imager®; Packard, Groningen, the Netherlands) as described previously [7]. The ratio of the preproET-1 mRNA signal and the corresponding GAPDH mRNA signal was calculated for each sample.

\section{ET-1 radioimmunoassay}

ET-1 radioimmunoassay was developed in the laboratoire de biologic hormonale by two of us (FM, JF). Synthetic peptide rat ET-1 [1-21] was synthesized with an automated peptide synthesizer (model 431 A; Applied Biosystems, Paris, France). Human and rat ET-1 amino acid sequences are identical [16]. ET-1 was iodinated by the chloramine T method. Specific activity of radiolabelled ET-1 was 2,300 Ci-mmol-1.

Immunoreactive ET was assayed in cell culture supernatants without extraction. Briefly, samples $(100 \mu \mathrm{L})$ and standards (synthetic ET-1) were reconstituted in assay buffer and incubated with rabbit anti-rat ET-1 anti-serum prepared in our laboratory by immunizing a rabbit with synthetic rat peptide ET-1 [1-21]. This was followed by the addition of ${ }^{125}$ I-labelled ET-1 (approximately $10^{4}$ counts per minute (cpm) per sample). Bound and free radioactivity were separated by the secondary antibody method, and gamma emission from the pelleted anti-body-ET complexes was counted using a gamma counter. Since, the antibody used exhibited a $75 \%$ and $60 \%$ cross-reactivity with ET-2 and big ET-1, respectively, the results are given as irET rather than ET-1. The intra- and interassay coefficients 
of variation were 7 and 13\%, respectively. The minimum detectable level is $2.5 \mathrm{pg} \cdot \mathrm{mL}^{-1}$. Undetectable irET was noted as zero. The irET concentration was normalized for the protein concentration in each dish and expressed as $\mathrm{pg} \cdot \mathrm{mg}^{-1}$ protein. We checked that the foetal bovine serum used in all the experiments did not contain any detectable irET in this assay.

\section{ET immunolabelling}

Rat ATII cells grown on glass coverslips were washed with PBS and fixed in acetone for $10 \mathrm{~min}$ at room temperature. Endogenous peroxidase was inhibited by incubation with $\mathrm{H}_{2} \mathrm{O}_{2}(3 \%)$ for $5 \mathrm{~min}$. Then, the slides were incubated with a normal goat serum for $30 \mathrm{~min}$ in order to avoid nonspecific binding. Excess serum was tipped off, and cell monolayers were overlaid for $30 \mathrm{~min}$ with a polyclonal rabbit anti-ET-1 antiserum (1:100 volume/volume (v/v) in PBS containing $0.1 \%$ bovine-serum albumin (BSA)). After several washes in PBS, cell monolayers were incubated for 10 min with a biotinylated goat anti-rabbit antibody, then incubated with streptavidin-peroxidase (Dako, Trappes, France) for $10 \mathrm{~min}$ and washed in distilled water. Peroxidase reaction was then revealed by diaminobenzidine (Dako) and $\mathrm{H}_{2} \mathrm{O}_{2}$ (3\%) Anti-irET positive cells appeared brown. Cell monolayers were counterstained with Harris haematoxylin (Ortho Diagnostic Systems, Bucks, UK). Monolayers where the first antibody was omitted or where pre-immune rabbit serum was used instead of the anti-ET-1 antiserum were used as controls in order to assess the specificity of the immunolabelling.

\section{Determination of irET in ATII cells lysates}

In order to evaluate intracellular irET, we measured irET in ATII cell lysates according to SumAMRA et al. [17]. ATII cells monolayers were washed with PBS and dispersed by trypsinization. After stopping trypsin action with DMEM with $10 \%$ foetal bovine serum and centrifugation, $0.5 \mathrm{~mL}$ of $0.1 \%$ trifluoroacetate and $0.1 \mathrm{~mL}$ pepstatin $\mathrm{A}$ in $50 \%$ acetonitril were added to the cell pellet and the cell suspension was sonicated for $15 \mathrm{~s}$. After centrifugation to remove insoluble materials, the supernatant was recovered and stored at $-80^{\circ} \mathrm{C}$ until irET assay.

\section{Determination of nitrite concentrations in ATII cell super- natants}

NO production by rat ATII cells cultured with $21 \% \mathrm{O}_{2}$ was estimated through the production of nitrite in cell culture supernatants using the colorimetric Griess reaction according to GR巴Net al. [18]. Sodium nitrite resuspen-ded in DMEM supplemented with $10 \%$ foetal calf serum (FCS) was used as a standard. One hundred microlitres of Griess reagent was added to $100 \mu \mathrm{L}$ of sample or standard and incubated in a 96-well plate at room temperature for $10 \mathrm{~min}$. The plate was read at $550 \mathrm{~nm}$ using a spectrophotometer. The lower limit of detection of the assay was 0.25 nmol. $100 \mu \mathrm{L}^{-1}$. Data are from three different experiments. The assays were performed in duplicate.

\section{Statistical analysis}

Data are presented as mean $\pm \mathbb{S B}$ The nonparametric Kruskall-Wallis test was used for statistical analysis, followed by the nonparametric Mann-Whitney U-test. A pvalue of less than 0.05 was considered significant. The results are from 3-8 different experiments performed in triplicate.

\section{Results}

\section{Rat alveolar type II cells secrete irET}

ET-1 radio immunoassay showed that ATII cells secreted irET in cell culture supernatant in a time-dependent manner (fig. 1). Immunoreactive ET could be detected in cell culture supernatants as soon as $1 \mathrm{~h}$ after incubation. ET concentration increased during the $24 \mathrm{~h}$ culture period. Immunoreactive ET secretion required $\mathrm{mRNA}$ and protein synthesis, since irET was not detected in the supernatant of ATII cells cultured with actinomycin D or cycloheximide.

In order to ascertain that ATII cells were indeed the primary source of ET in vitro, immunolabelling was performed on ATII cells cultured for $24 \mathrm{~h}$ on glass coverslips. Rat ATII cells demonstrated a strong cytoplasmic immunolabelling, which indicates that in vitro ATII cells contain irET (fig. 2).

\section{Change in ET-1 production over time in culture}

We measured irET in rat ATII cell supernatants and the preproET-1/GAPDH mRNA ratio at different times after isolation. Rat ATII cells were isolated on day 0, and studied on day 1, day 2 and day 3 after isolation. Fresh medium was placed on the cells on day 1 . We observed that the preproET-1/GAPDH mRNA ratio decreased from day

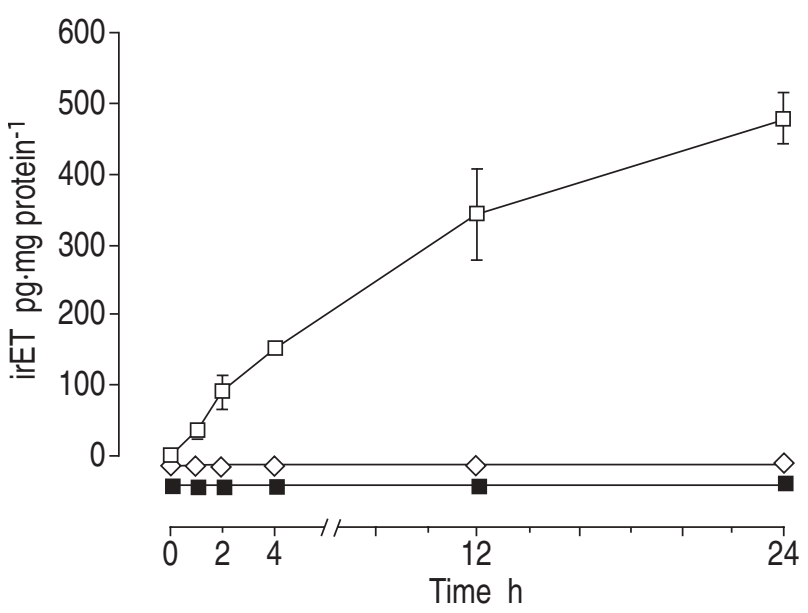

Fig. 1. - Time-dependent secretion of endothelin-1 by rat alveolar type II cells in vitro. Immunoreactive endothelin (irET)-1 was measured in the supernatant of rat alveolar type II cells cultured in Dulbecco's modified Eagle's medium (DMEM) with $10 \%$ foetal bovine serum in normoxic conditions $(\square)$. In some experiments, cells were cultured with cycloheximide $\left(20 \mu \mathrm{g} \cdot \mathrm{mL}^{-1} ; \diamond\right)$ or actinomycin $\mathrm{D}\left(5 \mu \mathrm{g} \cdot \mathrm{mL}^{-1} ; \boldsymbol{\square}\right)$. In these conditions, irET-1 was undetectable and was noted as zero. Results are from 3-6 experiments performed in triplicates. 

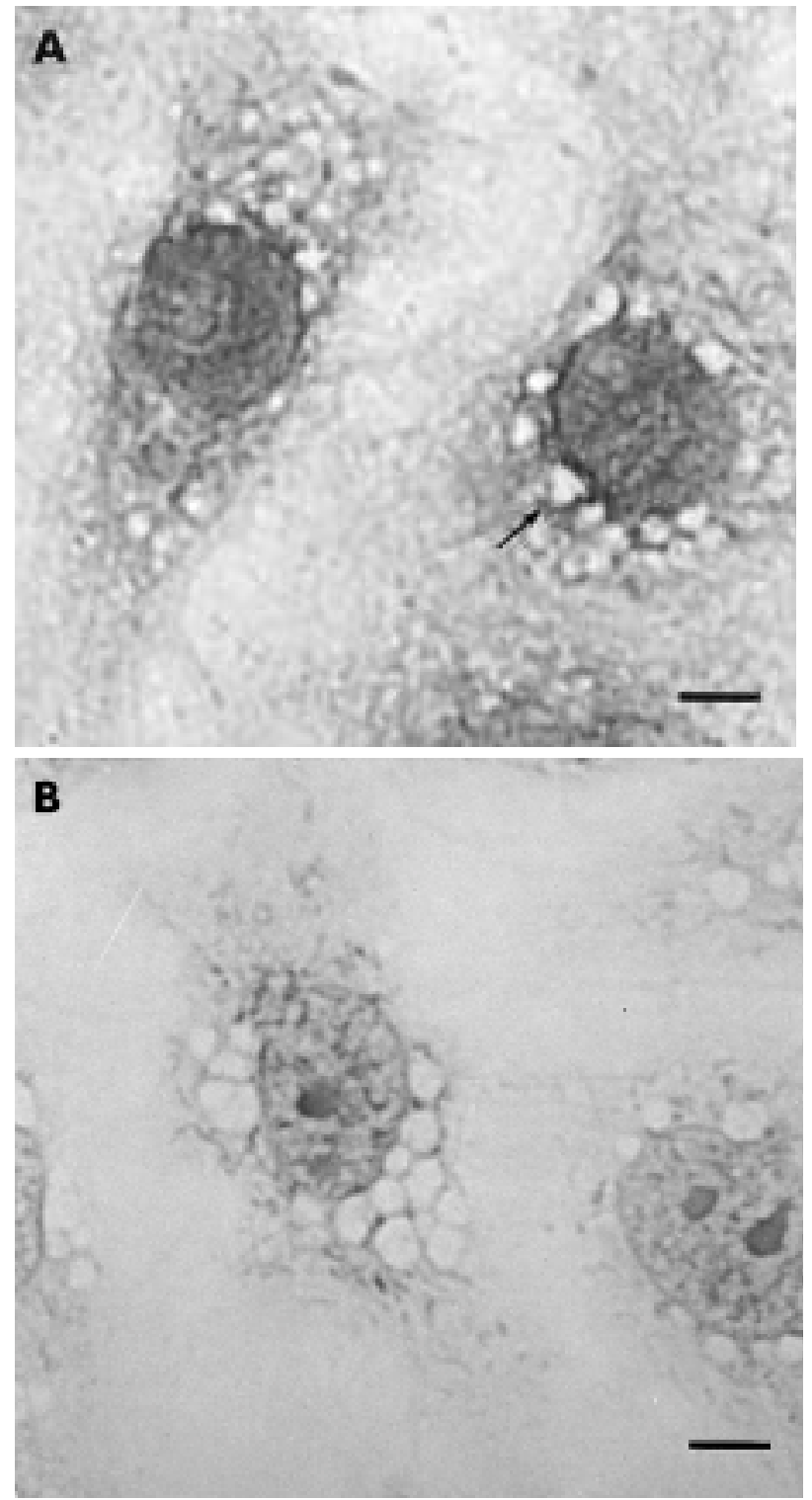

Fig. 2. - Endothelin immunostaining on rat alveolar type II cells in primary culture. A) rat alveolar type II cells (easily identified with their characteristic intra-cellular lipidic inclusions: arrow) exhibited a strong cytoplasmic immunolabelling; B) a control slide stained in the absence of primary antibody showed no staining. Internal scale bars $=10 \mu \mathrm{m}$.

1 to day 3 (fig. 3). At the same time, the ET concentration in rat ATII cell supernatants increased sharply from day 1 to day 2 and slightly from day 2 to day 3 .

Hypoxia decreases the secretion of irET by ATII cells in vitro

Exposure of ATII cells to a hypoxic atmosphere for increasing time periods reduced irET concentration in ATII cells supernatants (fig. 4). The reduction was statistically significant after $24 \mathrm{~h}\left(343 \pm 29 \mathrm{pg} \cdot \mathrm{mg}\right.$ protein $^{-1}$ with $1 \% \mathrm{O}_{2}$ versus $472 \pm 37 \mathrm{pg} \cdot \mathrm{mg}$ protein ${ }^{-1}$ with $21 \% \mathrm{O}_{2}, \mathrm{p}<$ 0.05). A similar decrease of ET concentration was measured in A549 cell supernatants when these cells were cultured for $24 \mathrm{~h}$ in hypoxic conditions $(512 \pm 102 \mathrm{pg} \cdot \mathrm{mg}$ protein $^{-1}$ with $1 \% \mathrm{O}_{2}$ versus $769 \pm 89 \mathrm{pg} \cdot \mathrm{mg}$ protein $^{-1}$ with $21 \% \mathrm{O}_{2}$ ) (fig. 4).
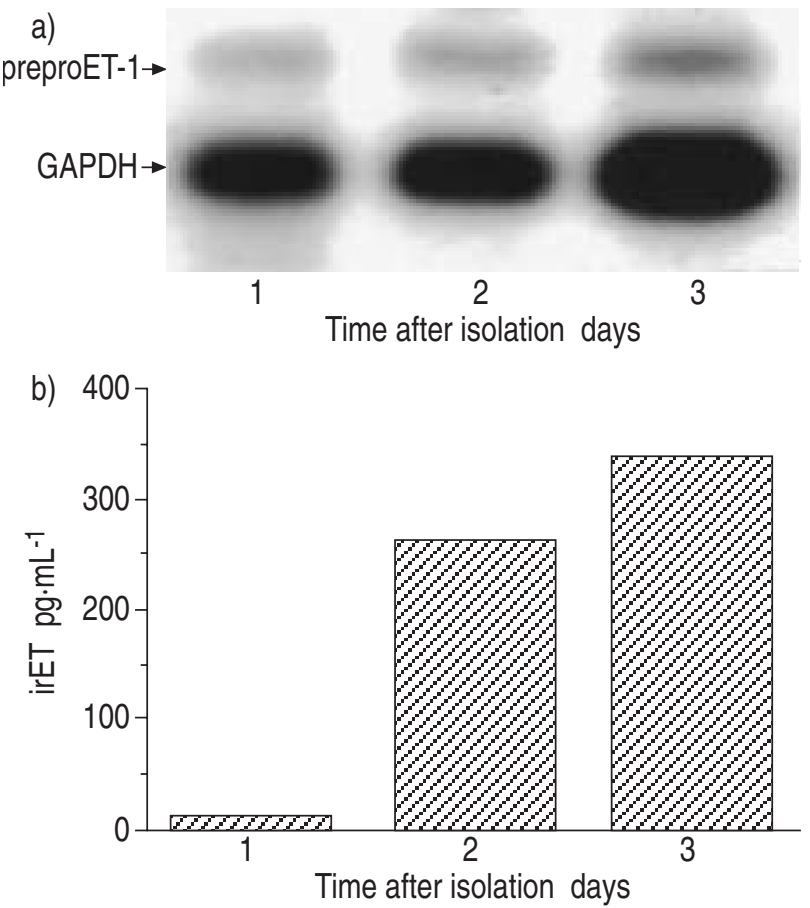

Fig. 3. - Changes in immunoreactive endothelin (irET) in rat alveolar type II (ATII) cell supernatants and preproendothelin-1 (preproET-1)/ glyceraldehyde-phosphate dehydrogenase (GAPDH) messenger ribonucleic acid (mRNA) ratio over time in culture. Rat (ATII) cells were isolated on day 0 and studied on days 1,2 and 3 after isolation. a) representative Northern blot showing preproET-1 mRNA and GAPDH mRNA in rat ATII cells cultured in normoxic conditions. The preproET1/GAPDH mRNA ratio, expressed as a percentage of the value at day 1 , was $94 \%$ on day 2 and $60 \%$ on day 3. b) representative graph showing variation in irET in rat ATII cell supernatants over time in culture. Data are from one experiment.

Intracellular ET, measured as ET concentration in ATII cell lysates, was not statistically different in ATII cells exposed to $1 \% \mathrm{O}_{2}$ or $21 \% \mathrm{O}_{2}$ for $24 \mathrm{~h}(35.0 \pm 1.3$ versus $30.0 \pm 2.7 \mathrm{pg} \cdot \mathrm{mL}^{-1}$, respectively) or $48 \mathrm{~h}(44.0 \pm 7.5$ versus $38.0 \pm 3.0 \mathrm{pg} \cdot \mathrm{mL}^{-1}$, respectively). This indicates that the reduction of ET concentration in ATII cell supernatants was not associated with an intra-cellular accumulation of ET.

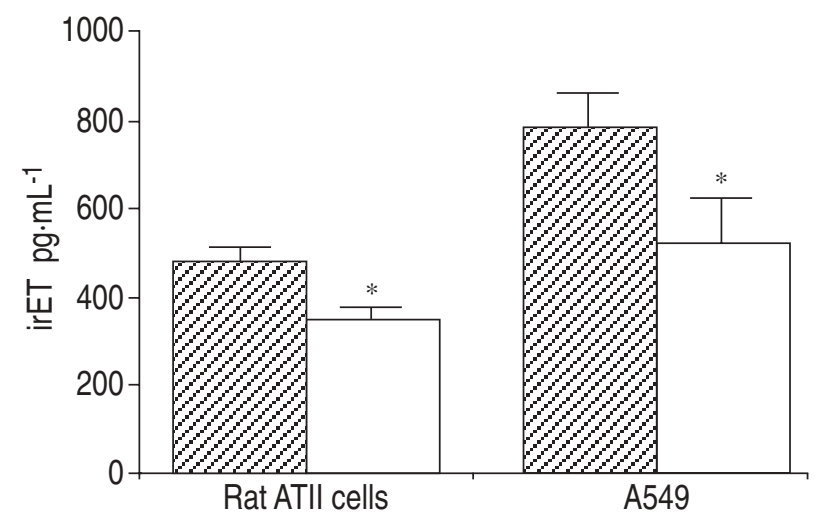

Fig. 4. - Hypoxia reduced immunoreactive endothelin (irET) secretion by rat alveolar type II (ATII) cells in primary culture and A549 cells. Cells were cultured for $24 \mathrm{~h}$ in either normoxic $\left(21 \% \mathrm{O}_{2} ; \angle 2\right)$ or hypoxic $\left(1 \% \mathrm{O}_{2} ; \square\right)$ atmosphere. $*$ : $\mathrm{p}<0.05,21 \% \mathrm{O}_{2}$ versus $1 \% \mathrm{O}_{2}$, Mann Whitney U-test. Values are mean \pm SEM, $n=6-8$ experiments. 


\section{Reversibility of the effect of hypoxia on irET secretion}

In order to determine whether the inhibition of ET secretion was reversible, we cultured ATII cells for $24 \mathrm{~h}$ in a $1 \% \mathrm{O}_{2}$ atmosphere. The cells were then returned to a $21 \%$ $\mathrm{O}_{2}$ atmosphere for $24 \mathrm{~h}$. The irET concentration in ATII cell supernatants increased with the return to a normoxic atmosphere (fig. 5) and reached the level of irET measured in the supernatant of ATII cells cultured for $24 \mathrm{~h}$ with $21 \% \mathrm{O}_{2}$. However, ET concentration remained lower than that measured in the supernatant of cells cultured in a normoxic atmosphere for $48 \mathrm{~h}$.

\section{Effect of hypoxia on ATII cell viability}

We explored rat ATII cell viability and A549 cell viability through the use of the colorimetric MTT assay (table 1). No significant alteration of the viability of rat ATII cells could be detected after 24 or $48 \mathrm{~h}$ exposure to a hypoxic atmosphere. Similarly, A549 cell viability was not modified after $24 \mathrm{~h}$ of hypoxia. However, a significant alteration of A549 cell viability was measured after $48 \mathrm{~h}$ of hypoxia.

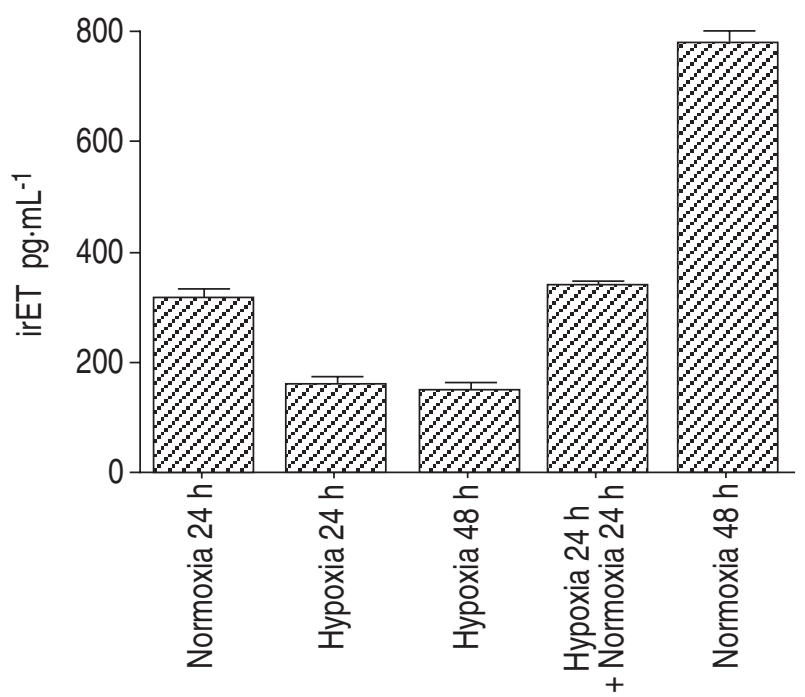

Fig. 5. - The effect of hypoxia on immunoreactive endothelin (irET) secretion by rat alveolar type II (ATII) cells is reversible. The irET concentration in ATII cell supernatants was measured when cells were exposed to $21 \% \mathrm{O}_{2}$ for $24 \mathrm{~h}$ or $48 \mathrm{~h}$, to $1 \% \mathrm{O}_{2}$ for $24 \mathrm{~h}$ or $48 \mathrm{~h}$, or to $1 \%$ $\mathrm{O}_{2}$ for $24 \mathrm{~h}$ then returned to $21 \% \mathrm{O}_{2}$ for $24 \mathrm{~h}$. Results are from a representative experiment performed in triplicates.

Table 1. - Viability of alveolar type II cells and A549 cells (MTT colorimetric assay)

\begin{tabular}{ccc}
\hline & \multicolumn{2}{c}{ Duration of exposure } \\
\cline { 2 - 3 } & $24 \mathrm{~h}$ & $48 \mathrm{~h}$ \\
\hline ATII cells & & \\
$21 \% \mathrm{O}_{2}$ & $100(4)$ & $72.6 \pm 5.7(4)$ \\
$1 \% \mathrm{O}_{2}$ & $91.8 \pm 4.3(4)$ & $78.9 \pm 3.3(4)$ \\
p-value & 0.21 & 0.26 \\
$\mathrm{~A} 549$ cells & & \\
$21 \% \mathrm{O}_{2}$ & $100(3)$ & $117.0 \pm 2.6(3)$ \\
$1 \% \mathrm{O}_{2}$ & $104.4 \pm 2.3(3)$ & $73.0 \pm 0.8(3)$ \\
p-value & 0.3 & 0.05 \\
\hline
\end{tabular}

Values are viabilities, expressed as a percentage of the control values at $21 \% \mathrm{O}_{2}$ and presented as mean $\pm \mathrm{SEM}$ and number of experiments performed in triplicates in parenthesis. The p-values derive from a Mann Whitney U-test.

\section{Effect of hypoxia on preproET-1 mRNA level}

Hypoxia increases the ET-1 secretion by human umbilical vein endothelial cells essentially at a transcriptional level [9]. By contrast, we observed that hypoxia reduced the preproET-1/GAPDH mRNA ratio in ATII cells to $40 \pm$ $6 \%$ of the control value ( $\mathrm{p}<0.01$ ) (fig. 6).

\section{Effect of NO on preproET-1 mRNA level}

We intended to determine whether the inhibition of ET1 production by ATII cells could be mediated by NO acting through a paracrine regulatory loop. In the first set of experiments, we attempted to ascertain whether rat ATII cells cultured with $21 \% \mathrm{O}_{2}$ produced NO. The production of $\mathrm{NO}$ was estimated through the production of nitrite. Nitrite accumulated in the supernatant of rat ATII cells in control condition $\left(1.0 \pm 0.4 \mathrm{nmol} \cdot 100 \mu \mathrm{L}^{-1}\right)$ and was strongly increased with an NO donor (SIN-1) (4.5 \pm 1.0 nmol.100 $\left.\mu \mathrm{L}^{-1}\right)$. Nitrite was undetectable when the cells were cultured with NO synthesis inhibitors (either $\mathrm{L}-$ NMMA or S-methylthiourea sulphate). The inhibition induced by L-NMMA was partially corrected with addition of $\mathrm{L}-\mathrm{Arg}\left(0.5 \pm 0.2 \mathrm{nmol} \cdot 100 \mu \mathrm{L}^{-1}, \mathrm{p}<0.05\right.$ when compared with control and L-NMMA) whereas nitrite concentration in ATII cell supernatants was not affected by L-Arg treatment $\left(0.9 \pm 0.5 \mathrm{nmol} \cdot 100 \mu \mathrm{L}^{-1}\right)$.

a)

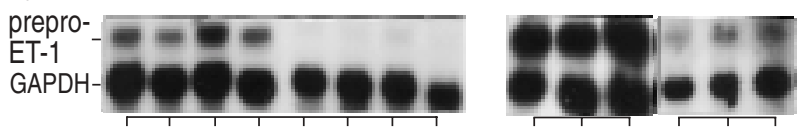

b)

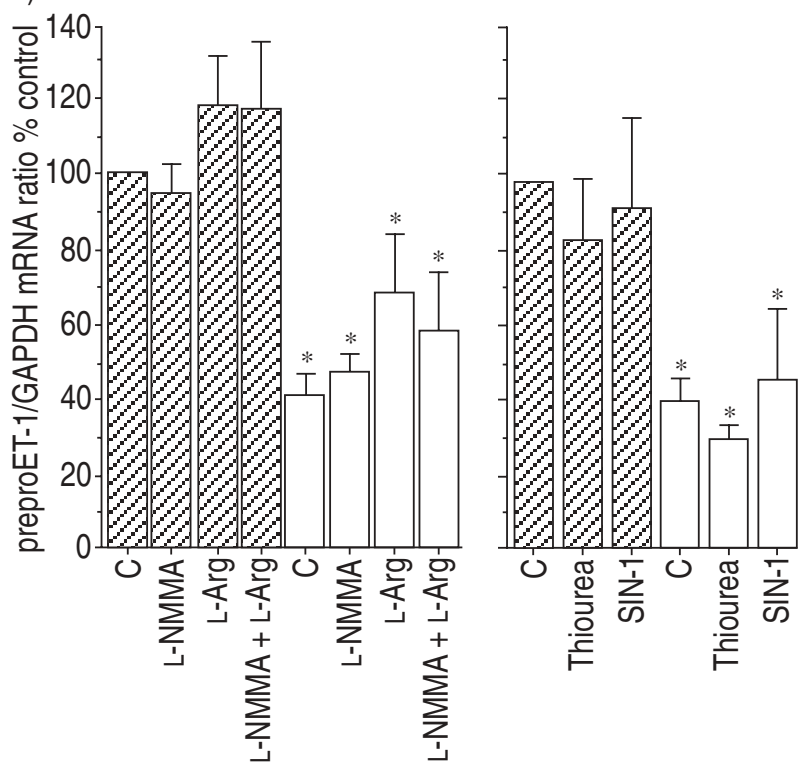

Fig. 6. - Nitric oxide does not influence preproET-1 mRNA content. a) typical Northern blots showing preproET-1 mRNA and GAPDH mRNA in rat ATII cells cultured with $21 \% \mathrm{O}_{2}(叉)$ ) or $1 \% \mathrm{O}_{2}(\square)$. The cells were cultured either in control conditions, or with $\mathrm{N}$-monomethyl Largenine (L-NMMA) $(0.5 \mathrm{mM})$, Thiourea $(1 \mathrm{mM})$, L-arginine (L-Arg; 5 $\mathrm{mM}$ ) or the combination of L-Arg and L-NMMA, or with an NO donor (SIN-1; $0.1 \mathrm{mM}$ ). b) PreproET-1/GAPDH mRNA ratio in rat ATII cells. Values are presented as mean \pm SEM $(\mathrm{n}=4$ experiments). $*$ : $\mathrm{p}<0.05$ versus normoxic control, Mann Whitney U-test. For definitions, see legend to figure 3 . 
In a second set of experiments, we observed that neither NO synthesis inhibition nor an NO donor (SIN-1) influenced the preproET-1/GAPDH mRNA ratio in rat ATII cells, either in normoxic or hypoxic conditions (fig. 6). Our results imply that changes in NO synthesis do not account for the hypoxia-induced decrease in irET release.

\section{Discussion}

Cultured rat ATII cells in primary culture express preproET-1 mRNA, contain irET in their cytoplasm and secrete high concentrations of irET. ET secretion by rat ATII cells requires mRNA expression and protein synthesis since both cycloheximide or actinomycin D completely inhibited ET secretion. Exposure of rat ATII cells to low oxygen tensions for up to $48 \mathrm{~h}$ reduced ET secretion and decreased the steady state level of preproET-1 mRNA without altering cellular viability. The inhibition was not mediated by NO. Hypoxia similarly reduced ET secretion by human A549 cells.

Endothelin secretion by nonvascular cells was demonstrated very early after the discovery of this new family of peptides. In normal human lung, the neuroendocrine cells of the bronchial tree have been shown to be the most important locations of ET-1 immunoreactivity and preproET-1 mRNA detection using in situ hybridization [19]. Immunoreactive ET could also be detected in other humans bronchial epithelial cells [19] and bronchial and tracheal epithelial cells have been shown to secrete irET-1 in culture [20]. Moreover, irET could be detected in the bronchoalveolar lavage fluid of normal subjects [21]. In the human lung, expression of irET-1 and preproET-1 mRNA by the hyperplastic alveolar epithelium appears to be a striking finding in interstitial pulmonary fibrosis with or without pulmonary hypertension [5, 22], whereas normal human lung tissue expressed very little ET-1. It must be noted that Uacaon et al. [6] found that ET-1 immunoreactivity was virtually confined to small vessel endothelial cells and absent in type II pneumocytes in idiopathic pulmonary fibrosis. The discrepancy between both results is unexplained. However, preproET-1 mRNA expression by hyperplastic alveolar epithelial cells has also been observed in the course of pulmonary vasculitis [4].

Oxygen tension has been shown to modulate ET-1 expression in vivo. In rats, normobaric hypoxia for $24 \mathrm{~h}$ or $48 \mathrm{~h}$ increases the steady-state level of preproET-1 mRNA in the lung, the right atrium and pulmonary artery by twofold [23-25], increases the level of endothelin A $\left(\mathrm{ET}_{\mathrm{A}}\right)$ receptor steady-state mRNA in the lung [25] and increases the levels of ET-1 in lung homogenates and plasma [25]. However, STHARR et al. [26] found that rats exposed to reduced barometric pressure $(54.5 \mathrm{kPa}(410$ $\mathrm{mmHg})$ ) for 3 weeks with consequent low $\mathrm{PO}_{2}(10.8 \mathrm{kPa}$ $(81 \mathrm{mmHg}))$ and development of pulmonary hypertension had normal ET-1 content and preproET-1 mRNA expression.

Although endothelins are widely distributed molecules, ET-1 gene transcription and translation into active protein product have been studied most extensively in cultured endothelial cells. In endothelial cells, ET-1 is expressed and released constitutively. Its production is thought to be regulated chiefly at the level of gene tran- scription and/or translation of the mRNA. Exposure to normobaric hypoxia increases the transcription of the preproET-1 gene and the secretion of ET-1 from cultur- ed human umbilical vein endothelial cells into the media [27]. Bovine coronary endothelial cells also increase ET-1 secretion when exposed to low oxygen tensions [28]. However, Bar et al. [29] have shown that the prepro- ET-1 mRNA content was reduced by hypoxia in Hela cells, in primary heart fibroblasts, in a human hepatoma cell line (HepG2), in normal rat kidney cells and in hum-an embryonic kidney cells. In rat lung endothelial cells, MARKENIZ et al. [10] have shown that hypoxia reversibly decreases ET-1 production by $50 \%$. In this cellular model, as we show for rat ATII cells, inhibiting constitutive NO synthesis does not prevent the decrease in ET-1 release caused by hypoxia. Altogether, these data indicate that the regulatory effect of hypoxia on preproET-1 gene expression may vary markedly depending upon the cell type and tissue involved.

Hypoxia may occur in many pathological conditions in which the involvement of NO has been demonstrated, including acute and chronic inflammation. The pathological importance of interaction between NO and ET-1 has been reported in the literature. In vivo studies demonstrated the potent participation of $\mathrm{NO}$ in mitigating the vasopressor action of ET-1 [30] and several in vitro studies indicate that NO reduces the formation of ET-1 via a cyclic guanosine monophosphate (GMP)-dependent mechanism [29]. Since hypoxia has been demonstrated to stimulate NO release [31], and ATII cells are known to secrete NO in some circumstances [32], we attempted to determine whether the inhibition of ET-1 production by ATII cells could be mediated by NO acting through a paracrine regulatory loop. Our results imply that changes in NO synthesis do not account for the hypoxia-induced decrease in ET-1 gene expression because neither NO synthase inhibitors nor NO donors modified preproET1 mRNA levels compared to control conditions, either in a normoxic or a hypoxic atmosphere. The means by which hypoxia decreased ET-1 production by rat ATII cells remains unresolved. Our results show that the reduction of ET-1 concentration in ATII cell supernatants was not associated with an intracellular accumulation of ET. Whether hypoxia acts directly on the expression of the preproET-1 gene or on the stability of preproET-1 mRNA is unknown. Moreover, whether hypoxia inhibits ET-1 gene expression through the inhibition of secondary secreted mediators, or through interaction with nuclear transcription factors induced by hypoxia, such as cyclic GMPdependent tyrosin kinase, a negative modulator of ET-1 gene, as already shown [29,33], is currently unresolved.

We observed that intracellular ET was not different in ATII cells exposed to a hypoxic or a normoxic atmosphere. Perhaps the discrepancy between hypoxia effects on extracellular ET and intracellular ET concentration could be explained if we measured different endothelins in the two samples because of the cross-reactivity of radioimmunoassay between ET-1 and ET-2 or ET-3. If not, the result may only reflect that in endothelial and epithelial cells, the production of ET-1 peptide is dependent on the level of mRNA transcription and that ET-1 secretion occurs through the constitutive pathway without further regulation at the level of exocytosis [34]. 
ET-1 has been shown to exert some immunoregulatory functions through its effect on immune effector cells. ET1 is a potent stimulator of human alveolar macrophages via an increase in intracellular calcium [35]. It induces the expression of membrane-associated markers, the release of fibronectin [36] and the secretion of oxygen radicals by normal human alveolar macrophages [35]. ET-1 also acts on the neutrophil to induce its aggregation [37], promote its adhesion to endothelial cells through the expression of membrane adhesion molecules [38] and to enhance its superoxide generation [39]. ET-1 could act also as an immunoregulatory peptide through its action on nonimmune cells. Indeed, ET-1 stimulates 15-lipoxygenase activity in the rat distal lung [3], binds to receptors on airway epithelial cells and initiates the production of a variety of arachidonic acid metabolites that may participate in the regulation of airway inflammatory responses [40]. An autocrine effect of ET-1 on ATII cells is possible since ET-1 stimulates in vitro surfactant secretion by rat ATII cells at a concentration of $10 \mathrm{nM}$ [41]. This concentration is probably achieved in vivo in the epithelial lining fluid in humans [21].

In conclusion, these broad spectrum properties suggest that in some pathological conditions, endothelin-1 secretion by alveolar epithelial cells could play a significant role in the homeostasis of the alveolar epithelium.

Acknowledgements: The technical assistance of M. Proult and E. Ulrich is gratefully acknowledged. The authors are grateful to T. Sakurai (Institute of Basic Medical Sciences, Tsukuba, Japan) for providing the rat preproET-1 complementary deoxyribonucleic acid probe.

\section{References}

1. Crestani B, Cornillet P, Dehoux M, Rolland C, Guenounou M, Aubier M. Alveolar type II epithelial cells produce interleukin-6 in vitro and in vivo. J Clin Invest 1994; 94: 731-739.

2. Battistini B, Chailler P, D'Orleans-Juste PNB, Sirois P. Growth regulatory properties of endothelins. Peptides 1993; 14: 385-399.

3. Nagase T, Fukuchi Y, Jo C, et al. Endothelin-1 stimulates arachidonate 15-lipoxygenase activity and oxygen radical formation in the rat distal lung. Biochem Biophys Res Comm 1990; 168: 485-489.

4. Ehrenreich HP, Burd PM, Rottem M, et al. Endothelins belong to the assortment of mast cell-derived and mastcell bound cytokines. New Biol 1992; 4: 147-152.

5. Saley D, Furukawa K, Tsao MS, et al. Elevated expression of endothelin-1 and endothelin-converting enzyme-1 in idiopathic pulmonary fibrosis: possible involvement of proinflammatory cytokines. Am J Respir Cell Mol Biol 1997; 16: 187-193.

6. Uguccioni M, Pulsatelli L, Grigolo B, et al. Endothelin-1 in idiopathic pulmonary fibrosis. J Clin Pathol 1995; 48: 330-334.

7. Odoux C, Crestani B, Lebrun G, et al. IL-1 $\beta$ inhibits ET-1 production by ATII cells in vitro: evidence for the involvement of cyclooxygenase 2 pathway. Am J Physiol (Lung Cell Mol Physiol 17) 1997; 273: L193-L200.

8. Markewitz B, Kohan D, Michael J. Endothelin-1 synthesis, receptors, and signal transduction in alveolar epithelium: evidence for an autocrine role. Am J Physiol (Lung Cell Mol Physiol 12) 1995; 268: L192-L200.
9. Kourembanas SK, Hannan RL, Faller DV. Oxygen tension regulates the expression of the platelet-derived growth factor-B Chain gene in human endothelial cells. J Clin Invest 1990; 86: 670-674.

10. Markewitz B, Kohan D, Michael J. Hypoxia decreases endothelin-1 synthesis by rat lung endothelial cells. Am J Physiol (Lung Cell Mol Physiol 13) 1995; 269: L215L220.

11. Crestani B, Rolland C, Petiet A, Colas-Linhart N, Aubier M. Cell surface carbohydrates modulate neutrophil adherence to alveolar type II cells in vitro. Am J Physiol (Lung Cell Mol Physiol 8) 1993; 264: L391-L400.

12. Mosmann T. Rapid colorimetric assay for cellular growth and survival: application to proliferation and cytotoxicity assays. J Immunol Methods 1983; 65: 55-63.

13. Bradford M. A rapid and sensitive method for the quantitation of microgram quantities of protein utilizing the principle of protein-dye binding. Anal Biochem 1976; 72 : 248-254.

14. Salzman A, Denenberg A, Ueta I, O'Connor M, Linn S, Szabo C. Induction and activity of nitric oxide synthase in cultured human intestinal epithelial monolayers. Am J Physiol (Gastrointes Liver Physiol) 1996; 270: G565G573.

15. Salvemini D, Currie M, Mollace V. Nitric oxide-mediated cyclooxygenase activation: a key event in the antiplatelet effects of nitrovasodilatators. J Clin Invest 1996; 97: 2562-2568.

16. Masaki T, Yanagisawa M, Goto K. Physiology and pharmacology of endothelins. Med Res Rev 1992; 12: 391-421.

17. Suwamura T, Kasuya Y, Matsushita Y, et al. Phosphoramidon inhibits the intracellular conversion of big endothelin-1 to endothelin-1 in cultured endothelial cells. Biochem Biophys Res Commun 1991; 174: 779-784.

18. Green J, Schotland S, Sella Z, Kleeman C. Interleukin-6 attenuates agonist-mediated calcium mobilization in murine osteoblastic cells. J Clin Invest 1994; 93: 2340-2350.

19. Giaid A, Polak JM, Gaitonde V, et al. Distribution of endothelin-like immunoreactivity and mRNA in the developing and adult human lung. Am J Respir Cell Mol Biol 1991; 4: 50-58.

20. Mattoli S, Mezzetti M, Riva G, Allegra L, Fasoli A. Specific binding of endothelin on human bronchial smooth muscle cells in culture and secretion of endothelin-like material from bronchial epithelial cells. Am J Respir Cell Mol Biol 1990; 3: 145-151.

21. Cambrey A, Harrison N, Dawes K, et al. Increased levels of endothelin-1 in bronchoalveolar lavage fluid from patients with systemic sclerosis contribute to fibroblast mitogenic activity in vitro. Am J Respir Cell Mol Biol 1994; 11: 439-445.

22. Giaid A, Yanagisawa M, Langleben D, et al. Expression of endothelin-1 in the lungs of patients with pulmonary hypertension. N Engl J Med 1993; 328: 1732-1739.

23. Elton TS, Oparil S, Taylor GR, et al. Normobaric hypoxia stimulates endothelin-1 gene expression in the rat. Am J Physiol 1992; 263: R1260-1264.

24. Donahue DM, Lee MR, Suen HC, Quertermous T, Wain JC. Pulmonary hypoxia increases endothelin-1 gene expression in sheep. J Surg Res 1994; 57: 280-283.

25. Li H, Elton T, Chen Y, Oparil S. Increased endothelin receptor gene expression in hypoxic rat lung. Am J Physiol (Lung Cell Mol Physiol 10) 1994; 266: L553-L560.

26. Stelzner TJ, O'Brien RF, Yanagisawa M, et al. Increased lung endothelin-1 production in rats with idiopathic pulmonary hypertension. Am J Physiol (Lung Cell Mol Physiol 6) 1992; 262: L614-L620. 
27. Kourembanas S, Marsden P, McQuillan L, Faller D. Hypoxia induces endothelin gene expression and secretion in cultured human endothelium. J Clin Invest 1991; 88: 1054-1057.

28. Hieda HS, Gomez-Sanchez CE. Hypoxia increases endothelin release in bovine endothelial cells in culture, but norepinephrine, serotonin, histamine and angiotensin II do not. Life Sciences 1990; 47: 247-251.

29. Bodi I, Bishopric NH, Discher DJ, Wu X, Webster KA. Cell-specificity and signaling pathway of endothelin-1 gene regulation by hypoxia. Cardiovasc Res 1995; 30: 975-984.

30. Filep JG, Foldes-Filip F, Rousseau A, Sirois P, Fournier A. Vascular response of endothelin-1 following inhibition of nitric oxide synthesis in the conscious rat. Br J Pharmacol 1993; 110: 1213-1221.

31. Pohl U, Busse R. Hypoxia stimulate release of endothelium-derived relaxing factor. Am J Physiol (Heart Circ Physiol) 1989; 256: H1595-H1600.

32. Asano K, Chee C, Lilly C, et al. Activity and gene expression of constitutive and inducible isoforms of nitric oxide synthase in human lung epithelial cells. Am $J$ Respir Crit Care Med 1994; 149: A551.

33. Kourembanas S, McQuillan LP, Leung GK, Faller DV. Nitric oxide regulates the expression of vasoconstrictors and growth factors by vascular endothelium under both normoxia and hypoxia. J Clin Invest 1993; 92: 99-104.

34. Shima H, Yamanouchi M, Omori K, Suguira M, Kawashima K, Sato T. Endothelin-1 production and endothelin con- verting enzyme expression by guinea pig airway epithelial cells. Biochem Mol Biol Int 1995; 37:
1001-1010.

35. Haller H, Schaberg T, Lindschau C, Lode H, Distler A. Endothelin increases $\left[\mathrm{Ca}^{2+}\right] \mathrm{i}$, protein phosphorylation, and $\mathrm{O}_{2}^{-}$production in human alveolar macrophages. $\mathrm{Am}$ J Physiol (Lung Cell Mol Physiol 5) 1991; 261: L478L484.

36. Chanez P, Vignola AM, Albat B, et al. Endothelin-1 induces the expression of membrane-associated markers and the release of fibronectin by normal alveolar macrophages. Eur Respir J 1993; 6: 478s.

37. Gomez-Garre D, Guerra M, Gonzalez E, et al. Aggregation of human polymorphonuclear leucocytes by endothelin: role of platelet-activating factor. Eur J Pharmacol 1992; 224: 167-172.

38. Lopez-Farre A, Riesco A, Espinos E, et al. Effect of endothelin-1 on neutrophil adhesion to endothelial cells and perfused heart. Circulation 1993; 88: 1166-1171.

39. Ishida K, Takeshige K, Minakami S. Endothelin-1 enhances superoxide generation of human neutrophils stimulated by the chemotactic peptide N-formyl-methionylleucyl-phenylalanine. Biochem Biophys Res Comm 1990; 173: 496-500.

40. Wu T, Rieves D, Larivee P, Logun C, Lawrence MG, Shelhamer JH. Production of eicosanoids in response to endothelin-1 and identification of specific endothelin-1 binding sites in airway epithelial cells. Am J Respir Cell Mol Biol 1993; 8: 282-290.

41. Sen N, Grunstein M, Chander A. Stimulation of lung surfactant secretion by endothelin-1 from rat alveolar type II cells. Am J Physiol (Lung Cell Mol Physiol) 1994; 266: L255-L262. 